\title{
CORRIGENDUM
}

\section{Chk1 phosphorylation of Metnase enhances DNA repair but inhibits replication fork restart}

R Hromas, EA Williamson, S Fnu, Y-J Lee, S-J Park, BD Beck, J-S You, A Leitao, JA Nickoloff and S-H Lee

Oncogene (2014) 33, 536; doi:10.1038/onc.2013.510

Correction to: Oncogene (2012) 31, 4245-4254; doi:10.1038/ onc.2011.586; published online 9 January 2012.

Since the publication of the above manuscript the authors have identified an error in the author list; the name of the eighth author was misspelled. The corrected author list is shown above. 